\title{
ICASSP 2018参加報告
}

\section{杉本 憲治郎}

本稿は, 2018年4月15日から 20 日にかけて, カナダ・アルバータ州・カルガリーで開催された国際会議 『The 43rd International Conference on Acoustics, Speech and Signal Processing (ICASSP 2018)』の参加 報告である. ICASSPは信号処理分野においてトップ国際会議に位置づけられており, 音声・映像・生体 信号・センサデータをはじめ, 基礎から応用まで幅広く, さまざまなジャンルの研究者が世界中から集う 年に一度の大イベントである。

キーワード：国際会議, 信号処理, 音響, 音声, 画像

\section{1.まえがき}

International Conference on Acoustics, Speech and Signal Processing (ICASSP) は, IEEE Signal Processing Society (SPS) 主催のフラグシップ会議の一つであり, 信号 処理の基礎理論やその応用を主なターゲットとしている. 音声・映像・生体信号 ・ 七ンサデー夕等の多種多様な「信 号」に関わる会議であるため, 幅広い分野の研究者が一堂 に集う貴重な場でもある. SPS主催のフラグシップ会議に は他にも International Conference on Image Processing (ICIP) とGlobal SIPがあるが, ICASSPはこの中で最も歴 史が長い.大会実行委員長によれば，第 1 回（1976年 @)フィデルフィア) 開催では, 発表 226 件 · 参加者 600 名 程度であったが, 現在では発表 1200 件超・参加者 2,000 名 超と, 信号処理分野の会議としては世界で最も大規模であ る.レクチャ・ポスタ発表は多数のセッションが同時並列 に実施されるためすべてを見ることはできない，近年では 運営側からスケジュール管理アプリが提供されており, 目 当ての発表を聴き逃さないよう, 発表の検索や通知機能を 駆使しながら会場を足早に行き来するのが定番のスタイル である. 採択率は例年 $50 \%$ 程度と目立って低いわけではな いが，世界中から良質な論文が多く集まることもあり，筆 者の主観では採択率以上に難易度は高く感じられる。

\section{ICASSP 2018 の概要}

2018年4月 15 日（日）から4月 20 日 (金)の6日間，カナダ・ アルバータ州・カルガリーにあるCalgary TELUS Convention Centerにて開催された。 公式発表のデータによれば，今年 は投稿論文 2830 本のうち 1406 本が採択され (採択率 49.7\%), スペシャルセッションは提案 48 件のうち採択 16 件, チュー

$\dagger$ 早稲田大学 大学院情報生産システム研究科

"Report on ICASSP 2018" by Kenjiro Sugimoto (Graduate School of Information, Production and Systems, Waseda University, Fukuoka)
トリアルは提案 42 件のうち採択 14 件とある。過去のICASSP と比較しても, 投稿論文数は歴代 2 位，スペシャルセッショ ンとチュートリアルの提案数に至っては共に歴代 1 位と, こ れまでで最大規模となったようである。これらは110個のポ スタセッションと77個のレクチャセッション (スペシャル セッション含む) で発表された.

図 1 に昨年 (薄) と今年 (濃) のICASSP の分野別の投稿数 を示す.今年の投稿数トップ 3 はSpeech Processing (SP) の529件, Machine Learning for Signal Processing (MLSP) の368件, Signal Processing Theory and Methods (SPTM) の331件である．昨年と比べるとSP・MLSPが大幅に増え， 逆にSPTMは大幅に減り昨年トップから順位を下げた。そ の他の分野は昨年とほぼ同様の傾向に見える。このMLSP 分野の投稿数の増加から, 機械学習の流行がICASSPにも 大きな影響を与えていることがわかる。またSPSが企画・ 出版するIEEE Signal Processing Lettersに掲載された研 究内容を発表するセッション (図中のSPL) も設けられた. 近年のSPS主催の他のフラグシップ国際会議でも同様のシ ステムが設けれており, いわゆる国際会議参加の新しい形 である. 周囲からの評判もよかったことから, 研究成果を より効率的に発信するための選択肢の一つとして今後普及 するかもしれない.

\section{3. テクニカルセッション}

テクニカルセッションはレクチャ発表とポスタ発表で構成 される。一件あたりの発表時間は, 前者が質疑応答込みで 20 分，後者は 2 時間である. なお，それぞれで発表内容の優 劣はないとのことである. 図2にポスタセッション会場の様 子を示す. 発表件数が多いこともあって会場は広く, ポス タ一件あたりのパネル面積も広い $($ 約 $244 \mathrm{~cm} \times 122 \mathrm{~cm})$. こ れだけ大きいと, ポス夕以外にも論文原稿や説明用のポス トイットなども貼ることができ，実際にそのような工夫を した発表者もみられた。いざ発表となると, その広いパネ 


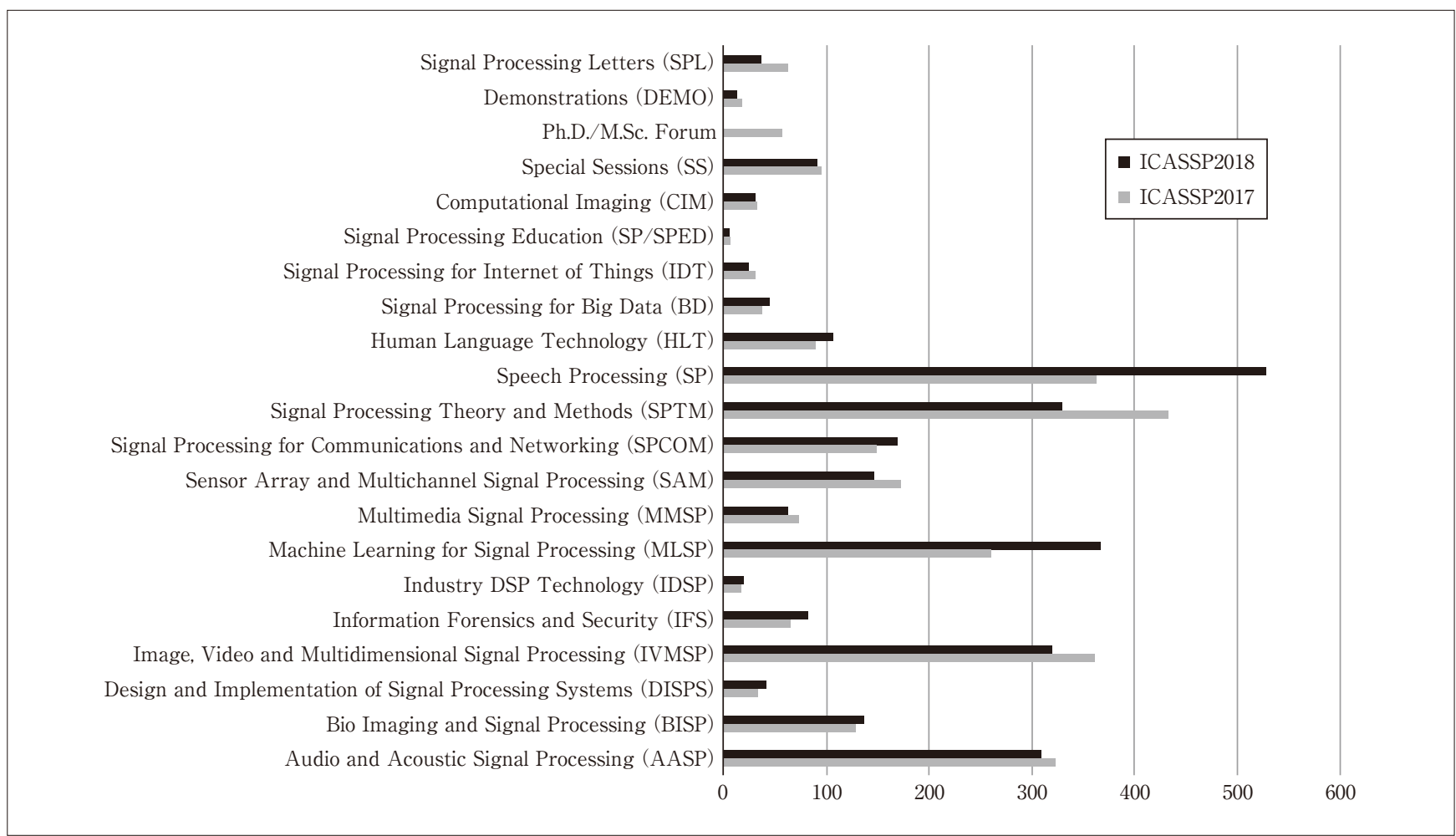

図 1 分野別の投稿論文数

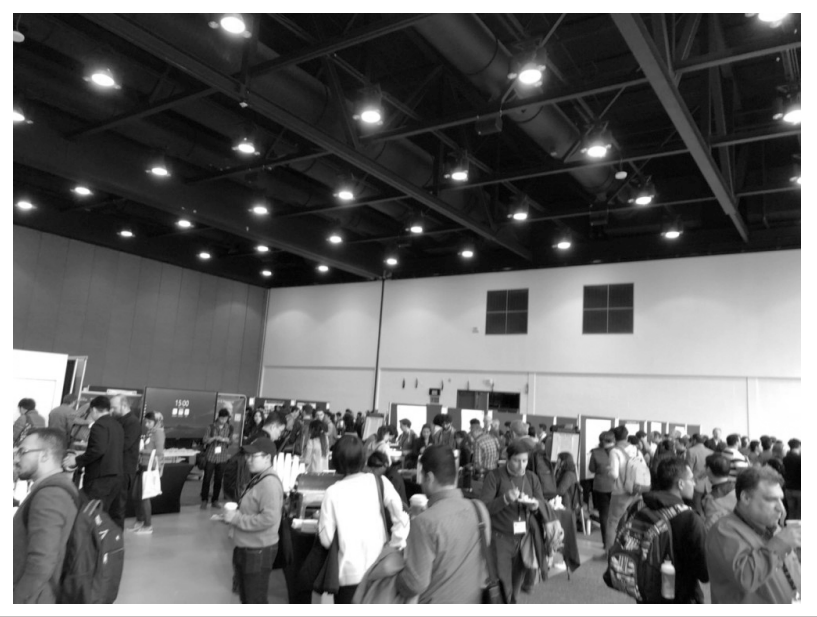

図2 ポスタセッション会場の様子

ルの前が多くの聴講者で埋まるほど盛況なセッションも あった。ポス夕発表会場では同時に企業のブースも多々展 示されていた。今回目立ったのは大きなブースを構えた多 数の中国企業のスポンサーである. 科学技術分野における 中国のプレゼンスの高まりをひしひしと感じた。

\section{4. バンケット}

僭越ながら，筆者が個人的に最も楽しめたイベントはバ ンケットである (!). 今年のバンケットでは, 参加者全員 にカウボーイハットの着用が義務づけられた. 参加登録の 際に頭の周長を計測して適切なハットサイズを選択するよ

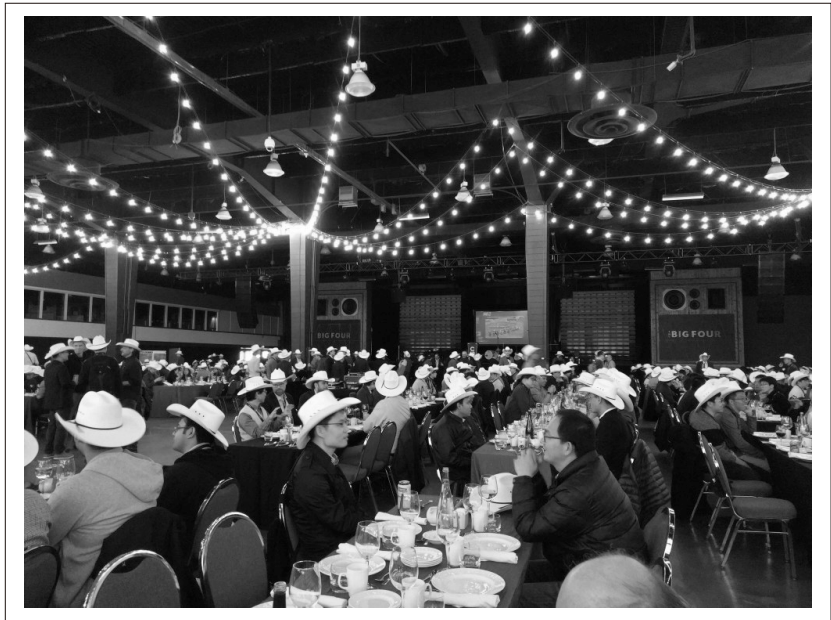

図3 バンケットで白いカウボーイハットを着用した参加者たち

う求められる徹底ぶりである。図3にあるように，参加者 全員が白いハットを着用した光景はなかなかユニークで あった。この日以降, 市街で白いハットを被った集団をし ばしば見かけるようになった。難点と言えば，事前にサイ ズ指定していたにもかかわらず希望サイズが不足していた 点 (筆者は一つ小さなサイズとなった) と, ハットがスーツ ケースに入らず帰路で手荷物が増えた点であろうか.

バンド演奏も大変盛り上がった。音楽と曲芸を融合した スタイルのバンドであったが, 特に驚いたのが会場の参加 者からのリクエスト曲の即興演奏である。ボーカリストに 目をつけられた参加者は思い思いに好きな曲 (とはいえ空気 
を読んだのか大半は世界的な有名曲）を答えるのであるが， そのリクエスト通りに10数曲を即興メドレーで演奏しきっ たのである．事前に打ち合わせしているようにはとても思 えず，会場全体が驚きにあふれていた。あとで聞いた話で あるが，SPS主催の国際会議ICIP2015@ケベックのバン ケットでもこのバンドが登場していたらしく，ひょっとす るとSPS 扮墨付きのカナディアンバンドなのかもしれない.

\section{5. 押し寄せる「AI」の波}

御多分に洩れずICASSPにもいわゆる「AI」の波が押し寄 せ, 今年の公式テーマは「Signal Processing and AI: Changing the World」と定められた. 基調講演 4 件のうち 2 件が深層学習に関するもので, 特筆すべきは, 深層学習の 先駆者の一人であるYann LeCun先生 (Facebook, ニュー ヨーク大学)の「Power and Limits of Deep Learning for Signal Understanding」であろう.どちらかと言えばまだ $\lceil\mathrm{AI} 」 の$ 影響が小さいと思われるICASSPにもついにやって きた感がある，事実，テクニカルセッションでも深層学習 を活用した研究は数多くあった. バンケットではGoogleや Amazonの中国人エンジニアたちと同席したが，いずれも 梁層学習やスマートスピーカに関わる業務に従事している そうだ，今年のICASSPや近年の業界の動向を丸ごと反映 したようなできごとであった.

\section{6. トラブル}

今回は多くのトラブルに見舞われた点も印象に残ってい る. 当初ICASSP 2018は韓国・ソウルでの開催を予定して いたが，ここ一年間の朝鮮半島の政治情勢悪化に対する䯚 念から，急遽カルガリーに場所を移した形となった。この 変更で当初の計画を変えざるを得ない研究者もいたと思わ れる。また $15 \cdot 16$ 日には関東一带で強風が吹き荒れ，多 くの日本からの参加者が搭乗予定であった成田発のエアカ ナダ便が欠航するハプニングもあった。旅程が大幅に乱れ 一日遅れでの到着となった参加者も多かったようである. 他方で無事に初日から参加できた研究者にもちょっとした トラブルがあった。それはやや季節外れの寒波による大雪 である。もちろんカルガリーは日本と比べて寒い地域では あるが, 現地の方によれば 4 月中旬にここまでの大雪が降 ることは珍しいそうである，筆者もからうじて持ってきて いた厚手のジャンパーを着て, 一歩一歩滑らないよう慎重 に歩いた(その結果，チュートリアルに遅刻した)，それか ら数日間, 道路脇に雪の塊が残っていた光景が目に焼きつ いている.

\section{7. カルガリーという街}

アルバータ州の州都であるカルガリーには，高層ビルが 立ち並ぶオフィス街といった雲囲気がある. 街の中心には 象徴であるカルガリータワー $(191 \mathrm{~m})$ がそびえ立ち, 夜は
虹色に光るなど派手に目立っている(図4)，市街地の至る 所にビルの 2 階同士をつなげた渡り廊下が設けられている。 これは極寒の冬に外に出ずに建物を往来する工夫であると いう, 会議場もこの構造であり, レクチャセッションとポ スタセッションの部屋が実は隣の建物に位置することに気 づかず，会議の序盤は道に迷うことが多かった，そんな都 会感のあるカルガリーにも，少し足を運べばバンフ (Banff) という有名な観光スポットもある(図5)。市街地とはまっ たく異なる景色であり, ゴツゴツした岩肌の雪山を背景に，

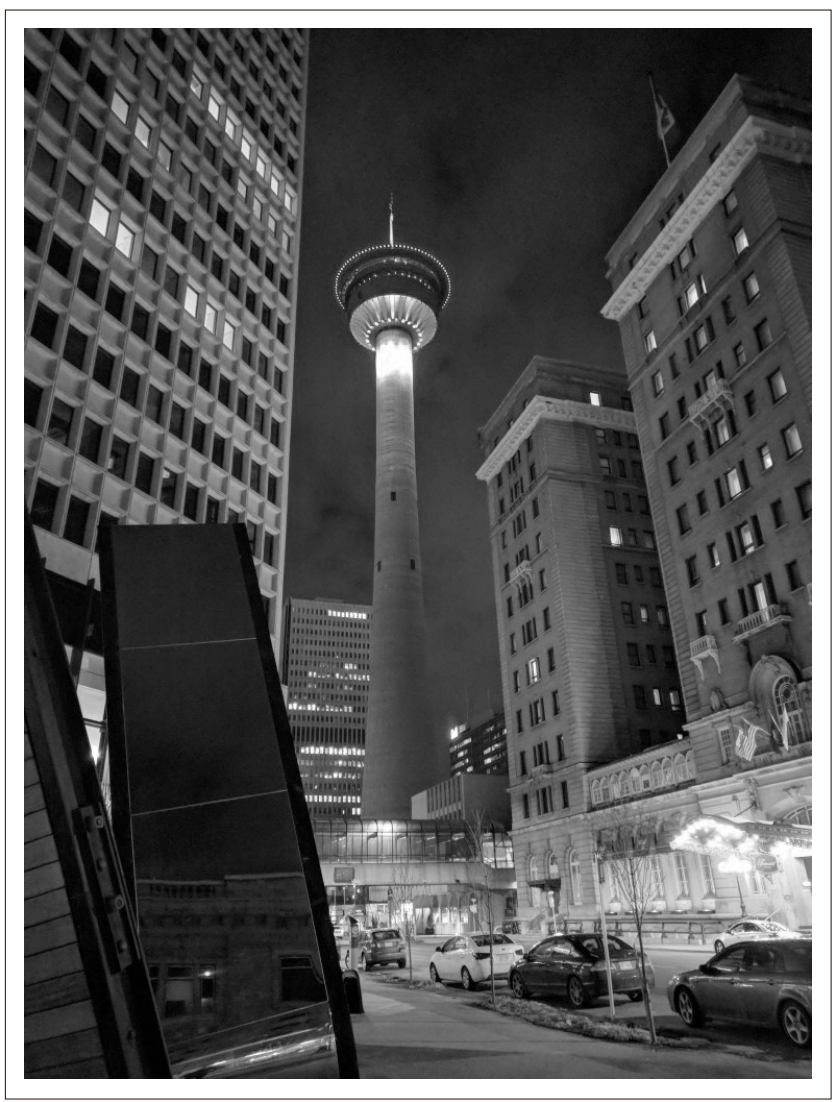

図4 市街地の中心にそびえ立つカルガリータワー

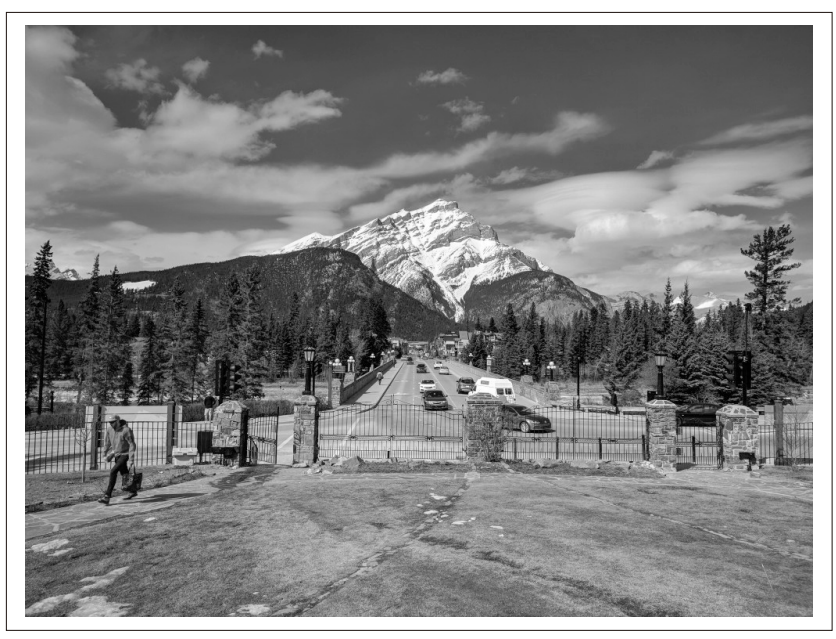

図5 バンフでの景色 


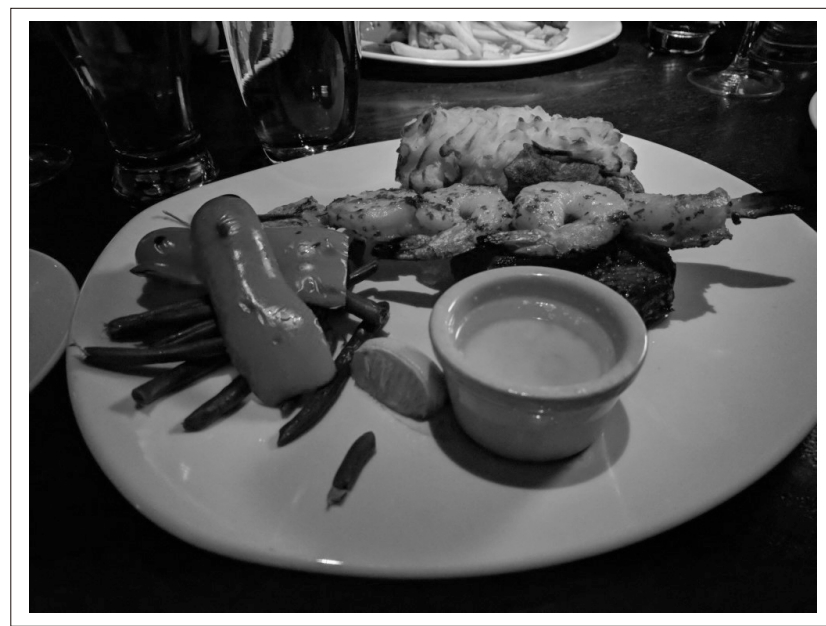

図6 大変美味しかったステーキ

深い緑色の森の間を雪解け水が流れる川といった, 自然に 溢れた「これぞカナダ」という光景も体験できる.

さて，国際会議と言えばやはり飯と酒である。市内の至 る所にレストランやバーがあり, 夜も大勢の人で賑わって いた、特にいくつかのバーでは世界中のビールを堪能でき， しかも価格が日本国内で飲むのに比べれば大変良心的であ る. 通貨はカナダドルであるが, 米ドルよりもレートが安 く，ドル円レートに慣れている身としては全体的にややお 得に感じられる。食べ物も個人的には口に合うものが多 かった。とはいってもステーキ・ハンバーガ・ポテト・ シーフードくらいしか食べていない気もする(図6). 酒と 肉の生活が連日続いたためか, 帰国後は体重が数 $\mathrm{kg}$ 増え ていたことは内緒である.
筆者にとっては初カナダ，そして初カルガリーであった が，抱いた印象は「とにかく人が親切で優しい」である. バーやレストランに行けばスタッフから気さくに声をかけ られ，オーダを伝える度に満面の笑みで“Awesome!”, “Sounds good!”, “Great!”などとなぜかひたすら褒めちぎ られる。バーでは隣で飲んでいた現地人グループと一緒に 盛り上がる（特にカウボーイハットはツボだったようだ）な ど，これまでの国際会議ではあまりなかった珍しい体験が たくさんあった．景色を撮らうとすれば後らの歩行者が気 づかって笑顔で立ち止まってくれたり， タクシーやUber のドライバも気さくに話しかけてくれたり，多くの方々が ホスピタリティに溢れていた．英語話者の国ということで そもそも意思蹯通しやすかった面もあるかもしれない。こ のようにすっかりとカナダが好きになったことは言うまで もない.

\section{8. 次回の日程および開催地}

次回は, 2019 年 5 月 12 日から 17 日にかけて英国・ブライ トンにて開催予定である。一般論文の投稿締切は2018年 10 月 29 日, 結果通知は 2019 年 2 月 1 日と設定されている.

(2018年5月 30 日受付)

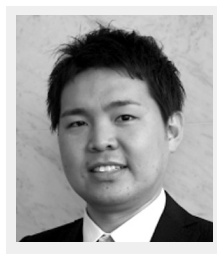

杉本憲治郎 2015年, 早稲田大学大学院情報生産 システム研究科博士課程修了. その後, 英国. Durham大学の Visiting Research Scientist, 早稲田大 学情報生産システム研究センターの助手・次席研究員 を経て, 2018年より, 早稲田大学大学院情報生産シス テム研究科・講師. 画像処理・パターン認識の研究に 従事. 博士 (工学). 